\title{
CERTAIN EFFECTS OF GLACIAL EVENTS IN THE VALE OF GLAMORGAN, SOUTH WALES
}

\author{
By C. B. Crampton \\ (Soil Survey of England and Wales, Rothamsted Experimental Station, Harpenden, \\ Hertfordshire, England)
}

\begin{abstract}
Arstract. In South Wales there is evidence for two phases of intense glaciation and an interglacial phase during the Pleistocene. During the closing stages of the earlier glaciation in the west of the Vale of Glamorgan two overflow channels were cut by melt water from an ice lobe off the Glamorgan upland, abutting against ice from the Irish Sea. During retreat, ice from the Irish Sea and local ice deposited material on the Lower Lias outcrop on which two contrasting soils developed. Soils normally associated with a Mediterranean climate developed locally on the outcrop of the Carboniferous Limestone during the interglacial phase.
\end{abstract}

RÉSumÉ. Aspects certains de phénomènes glaciaires dans le Vale of Glamorgan, Pays de Galles méridional. Dans le Pays de Galles méridional, il existe des traces évidentes de deux phases d'intense glaciation et d'une phase inter-glaciaire durant le Pléistocène. Pendant la fin de la glaciation la plus ancienne, dans l'ouest du Vale of Glamorgan, deux canaux de débordement ont été creusés par les eaux de fonte venant d'un lobe de glace au-dessus des terres hautes du Glamorgan touchant la glace de la Mer d'Irlande. Pendant le retrait, la glace de la Mer d'Irlande et la glace locale ont déposé du matériel sur l'affleurement du lias inférieur sur lequel se sont développés deux sols différents. Un sol normalement associé à un climat méditerranéen s'est développé localement sur un affleurement de grès carbonifère pendant la phase inter-glaciaire.

Zusammenfassung. Gewisse Auswirkungen glazialer Ereignisse im Vale of Glamorgan, Süd-Wales. In Süd-Wales lassen sich zwei Phasen von starker Vergletscherung und eine zwischeneiszeitliche Phase während des Pleistozäns nachweisen. Im Endstadium der ersten Vergletscherung wurden im Westen des GlamorganTales zwei Überlaufrinnen durch Schmelzwasser eines Eislappens abgeschnitten, der vom Glamorganer Hochland herabkam und gegen Eis aus der Irischen See grenzte. Während des Rückzugs lagerte Eis aus der Irischen See und lokales Eis auf die anstehende Untere Lias Material ab, auf dem sich zwei gegensätzliche Böden entwickelten. Auf dem anstehenden karbonischen Kalkstein entwickelten sich örtlich während der zwischeneiszeitlichen Phase Böden, die normalerweise in mediterranem Klima vorkommen.

\section{Physiography}

Figure I shows the regional physiography of South Wales. Blaenau Morgannwg (or the Glamorgan upland) is occupied by Carboniferous rocks, which are surrounded to the north by Old Red Sandstone rocks constituting the high land of the Brecon Beacons, Fforest Fawr and the Black Mountains. The east-west strip of lowland, delimited by Blaenau Morgannwg to the north and the Glamorgan coastline to the south, is known as the Vale of Glamorgan (or Bro Morgannwg). The part of the lowland south of Blaenau Morgannwg and enclosed by a terminal moraine is called Bro Miskin. Interbedded limestones and shales of the Lower Lias crop out where the Vale of Glamorgan adjoins the coastline, encircled to the north by the outcrop of the Carboniferous Limestone. Limestones and conglomeratic limestones become increasingly important in the Lower Lias succession west of the Vale of Glamorgan (Trueman, I922).

The Vale of Glamorgan was invaded by two distinct ice sheets during the earlier Pleistocene glaciation. One, from the Irish Sea, collected material from the Lake District and North Wales, flowed down the Irish Sea, turned eastwards across the south-western peninsula of Wales, and entered the Vale of Glamorgan, reaching Cardiff (Griffiths, I939) and probably beyond (Crampton, I960). During its retreat, this ice deposited debris across the low plateau of the Lower Lias outcrop adjacent to the coastline. The other ice flow, originating in the Brecon Beacons-Fforest Fawr range area (Robertson, I932), traversed Blaenau Morgannwg and met ice from the Irish Sea in the Vale of Glamorgan. Ice from the Irish Sea moving into the Bristol Channel dammed the river mouths, impounding glacial lakes (Pringle and George, I948). The Ewenny-Ogmore valley was probably one such glacial lake.

Charlesworth ( 1929 ) has traced the deposits of the last glaciation (the Newer Drift) and has shown they are not as extensive as those of the first glaciation (the Older Drift). During 


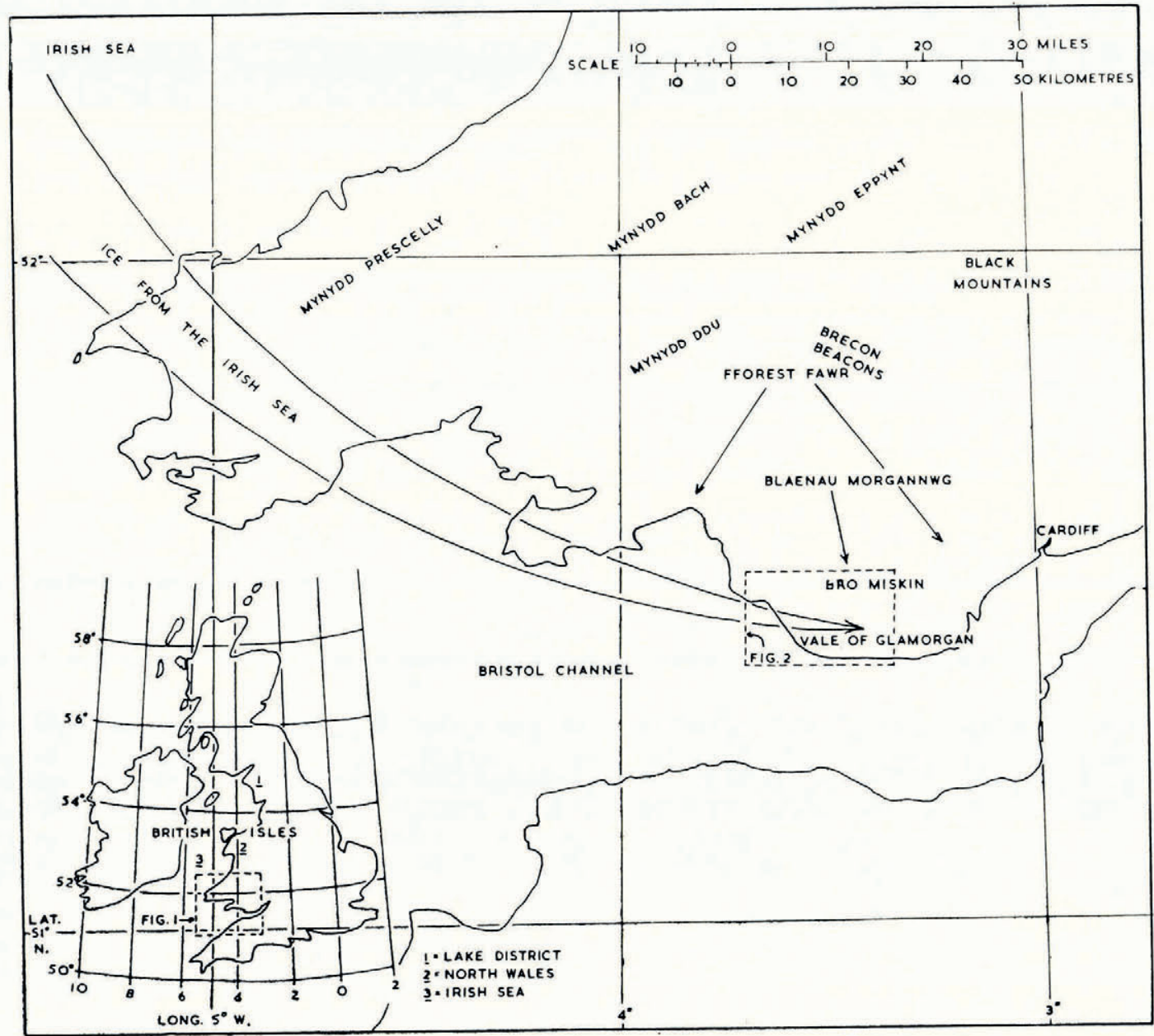

Fig. I. The general pattern of glaciation in South Wales

this later glaciation ice from the Irish Sea did not reach the Vale of Glamorgan, and Newer Drift from the Brecon Beacons-Fforest Fawr range area does not extend beyond the terminal moraine encircling Bro Miskin. Thus the Lower Lias plateau adjoining the coastline was not glaciated during the last glaciation.

Figure 2 shows the physiography of that part of the area being studied. West of the Vale of Glamorgan the prominent ridge of Carboniferous Limestone extends east-west from Penllyn to the coast at Ogmore, having three major crests exceeding $300 \mathrm{ft}$. (91 m.) o.D.: Crack Hill ( $325 \mathrm{ft}$. (99 m.) o.D.), Tair-Croes Down (316 ft. (96 m.) o.D.) and Beacons Down (33 I ft. (roI m.) o.D.). Between Beacons Down near the coast and the central Tair-Croes Down are the Alun and St. Bride's Gorges, deepening and converging northwards to join on the north side of the ridge, and isolating Old Castle Down between them.

Alongside the southern flank of the Beacons Hill-Crack Hill ridge, along the line of weakness following the junction between the Carboniferous Limestone and Lower Lias rocks, there is an elongated depression passing through Stembridge. This, "Stembridge depression", is $\mathrm{I} 47 \mathrm{ft}$. (45 m.) o.D. in the central basin, rising to $200 \mathrm{ft}$. (6I m.) O.D. east and west as the 


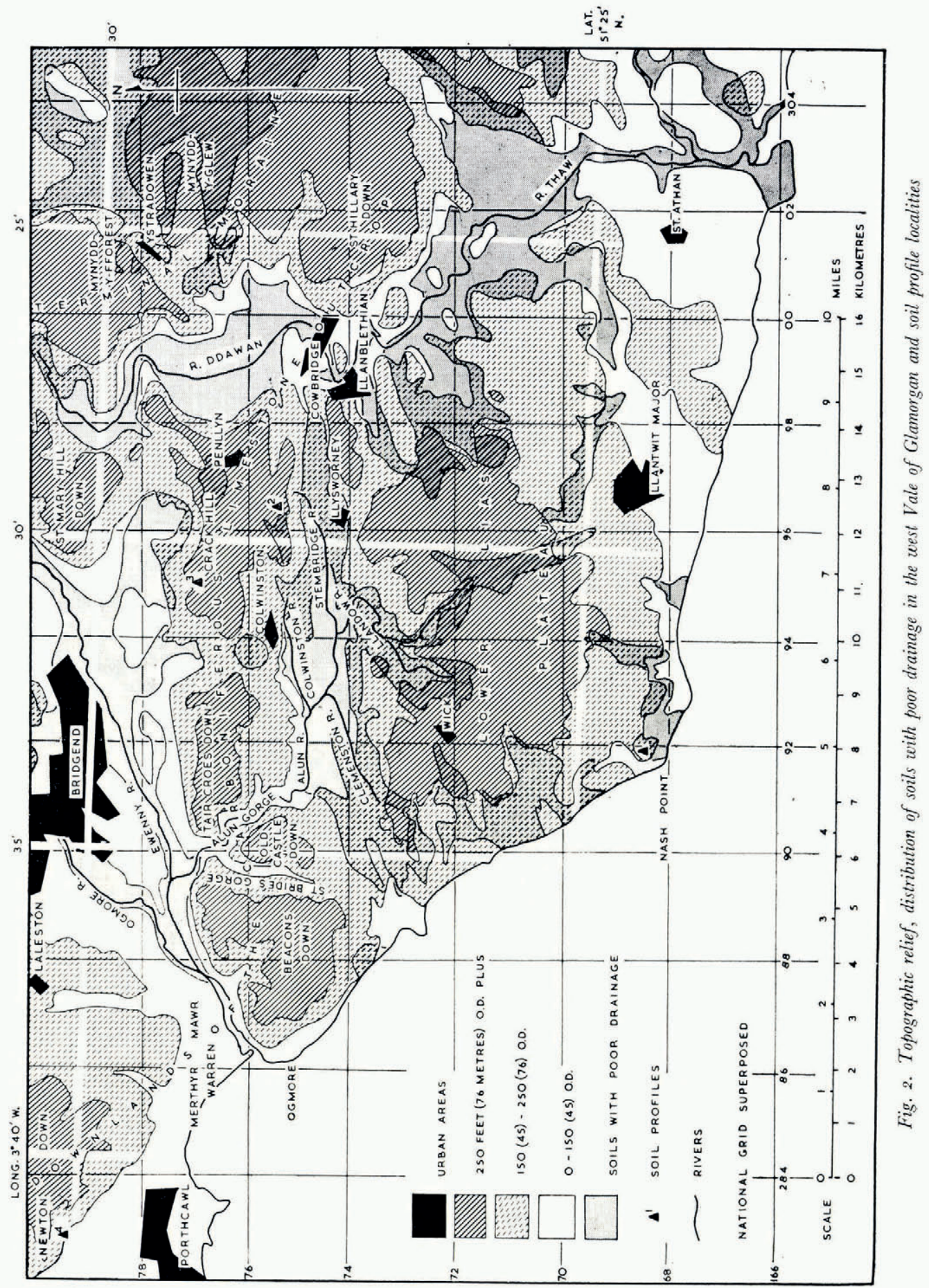


depression tapers out. Towards the east the depression passes into two shallow ravines which lead gently down to the broad valley of Afon Ddawan, but westwards it tapers out in a rather irregular fashion.

Clemenstone, Stembridge and Colwinston Brooks drain the central basin of the Stembridge depression, joining to form Afon Alun which turns north-west to plunge through Alun Gorge. St. Bride's Gorge is a dry valley, not so deep as Alun Gorge, and joining the Stembridge depression at a higher point to the west of Alun Gorge. Llandow Brook occupies a minor depression branching south from the Stembridge depression.

\section{SoILS}

The depressions are occupied by shallow, poorly drained soils (e.g. profile I). The Lower Lias limestone is massive and in places conglomeratic in the west of the Vale of Glamorgan, and there is insufficient shale in the rock to account for the fine textures of the soils. Finetextured soils with poor drainage are more widespread to the east of the Vale of Glamorgan where shale is more important in Lower Lias rocks, implying that it contributes some material to the overlying soil. However, the extensive occurrence of fine-textured soils with poor drainage to the west of the Vale of Glamorgan, not only in depressions such as the Stembridge depression but locally on hill crests such as near Llanmihangel, implies a source of fine material other than Lower Lias shale. Mineralogical evidence (Crampton, I96r) indicates these soils contain fine material carried by ice from Blaenau Morgannwg. Further evidence of glacial origin, in this case a local origin of part of the parent material of the soil, is the frequent presence in lower soil layers of Lower Lias limestone cobbles, which sometimes form a distinct layer over the rock strata, as in profile $\mathrm{I}$, in places up to $\mathrm{Io} \mathrm{ft}$. $(3 \mathrm{~m}$.) deep.

Freely drained soils over Lower Lias rocks south of the Stembridge depression (e.g. profile 2) contain rock fragments characteristic of drift carried by ice from the Irish Sea (Griffiths, I939). Mineralogical evidence (Crampton, I96r) indicates that soils either side of the Stembridge depression (e.g. profile 3) contain considerable quantities of wind-blown material, carried inland during post-glacial times, and the extensive sand dunes of Merthyr Mawr are a visible indication of the extent of aeolian transportation in the area. Because both gorges and soils occur south of the Newer Drift limit, they probably originated during the closing stages of the first glaciation and during the succeeding interglacial phase.

The shallow, freely drained soils on the various limestones cropping out in the Vale of Glamorgan have been likened to the terra fusca (Crampton, i964), defined by Kubiena (1953) as a soil characteristic of temperate regions. In places on the Carboniferous Limestone (e.g. some parts of the southern slopes of Newton Down), a shallow, bright red-coloured silty clay occurs (profile 4). Like the terra fusca, this soil contains abundant ferri-manganiferous concretions, but instead of a preferred orientation of clay being confined to birefringent flakes, the clay throughout displays considerably more evidence of orientation. This fabric is more akin to that characteristic of the terra rossa described by Kubiena (I953) - a soil occupying pockets in the limestone outcrop of areas receiving a hot and dry Mediterranean climate. Ball (ig6o) has similarly interpreted a red clay band on Worm's Head in Gower, and such an interpretation is consistent with the formation of these soils during the interglacial phase.

\section{Discussion}

The Stembridge depression was probably eroded during an early phase of the earlier glaciation, the rocks being gouged out by ice moving along the junction between the Carboniferous and Lower Lias, a line of weakness. Whilst Ewenny Valley may have been a glacial lake during the late stages of the first glaciation, the Stembridge depression is not occupied by lake deposits and so was not the site of a lake. It is suggested that the depression was occupied by an 
ice lobe from Blaenau Morgannwg, as this ice extended farther south during the first glaciation, abutting against ice from the Irish Sea. During the late stages of the first glaciation the Beacons Down-Crack Hill ridge was, presumably, not covered by ice. With glaciers retreating, melt water would be forced by the surrounding ice masses to flow across the ridge into Ewenny Lake. As the climate improved, the flow of melt water became vigorous and cut down into the limestone ridge, eventually forming the St. Bride's Gorge.

\section{Table i. Descriptions of Typical Soil Profiles}

\section{Profile 1 : Poorly drained over Lower Lias lime- stone and shale. Gently sloping with south- west aspect, at $150 \mathrm{ft}$ $(46 \mathrm{~m}$.) O.D., near Nash Point. \\ $\mathrm{O}-5$ in. (0-1 $3 \mathrm{~cm}$.) : Dark grey, ${ }^{*}$ friable $\dagger$ loam to silt loam, with blocky structure, $\uparrow$ con- taining intimate org- anic matter and earth- worms. $\mathrm{pH}_{5} \cdot 3$. Merg- ing boundary.}

5-10 in. ( $13^{-25} \mathrm{~cm}$.): Mottled, dark greybrown and brownish yellow, labile clay, with blocky structure, containing some roots, limestone fragments and a few earthworms. $\mathrm{pH} \quad 5 \cdot 6$. Merging boundary.

IO-I 5 in. $\quad\left(25-3^{8} \mathrm{~cm}.\right)$ : Grey, with prominent and common, brownish yellow mottles, plastic clay, with prismatic structure, containing a few roots, and limestone fragments. pH 6.5. Sharp boundary with limestone cobbles, over limestone strata.

\section{Profile 2: Freely drained over Lower Lias lime- stone and shale. Flat hilltop, at $270 \mathrm{ft}$. $(82$ m.) o.D., 0.5 miles $(0.8 \mathrm{~km}$.) south-west of Penllyn.}

$\mathrm{O}-4$ in. $(\mathrm{o}-\mathrm{Io} \mathrm{cm}$.): Dark grey brown, labile clay loam to silty clay loam, with subangular blocky structure, containing intimate organic matter and small limestone fragments. $\mathrm{pH} 6 \cdot \mathrm{r}$ Merging boundary.

4-10 in. ( $10-25 \mathrm{~cm}$.) : Yellowish brown, labile, silty clay loam to silty clay, with blocky structure, containing many roots, organic matter in root channels and numerous limestone fragments. pH 6.8. Sharp boundary with jointed limestone.

\section{Profile 3: Freely drained over Carboniferous Limestone. Gently sloping with north- west aspect, at $300 \mathrm{ft}$. (9 I m.) O.D., 0.5 miles $(2.4 \mathrm{~km}$.) west of Penllyn. \\ o-6 in. (o-15 cm.): Dark reddish brown, friable, silt loam, with crumb structure, containing intimate organic mat- ter, earthworms and limestone fragments. $\mathrm{pH} 7 \cdot 0$. Merging boundary.}

6-12 in. ( $15-30 \mathrm{~cm}$.$) :$ Reddish brown, friable silt loam, with subangular blocky structure, containing many roots, some earthworms and many limestone fragments. $\mathrm{pH}$ 7.5. Sharp boundary with jointed limestone.
Profile 4: Freely drained over Carboniferous Limestone. Steeply sloping with southwest aspect, at $200 \mathrm{ft}$. (6 I m.) O.D., $\mathrm{I} \cdot 5$ miles $(2.4 \mathrm{~km}$.) north-northeast of Porthcawl.

$\mathrm{O}-5$ in. (o-1 3 cm.) : Dark red, labile, silty clay loam, with granular structure, containing intimate organic matter and limestone fragments. $\mathrm{pH}_{5} \cdot 5$ Merging boundary.

$5^{-1} 3$ in. $\quad(13-33 \mathrm{~cm}$.): Red, plastic, silty clay, with massive structure, containing many roots and many limestone fragments. $\mathrm{pH}$ $6 \cdot 2$. Sharp boundary with jointed limestone.

\footnotetext{
* Soil colour notation according to Munsell.

$\uparrow$ Structure and consistency notation according to Soil Survey of Great Britain, Field handbook, 1960.
}

Continued retreat of the ice eventually left St. Bride's Gorge too high to act as an outlet for melt water, and a fresh course was cut across the ridge, giving rise to Alun Gorge. Presumably, this gorge acted as an outlet for melt water from the diminished ice lobe occupying Stembridge depression for longer than St. Bride's Gorge, and as a result was incised more deeply. Eventually only the central and lowest basin in the Stembridge depression was occupied by ice. The highly vigorous stream would be capable of lowering the mouth of the gorge as the ice lobe shrank, until the last vestige of ice had gone. The Alun Gorge then acted as an outlet for rivers draining the central basin of the Stembridge depression, continuously through the following interglacial phase, the last glaciation and to the present, whilst St. Bride's Gorge was left dry. 
Aciknowledgements

The author is indebted to J. A. Catt and D. A. Osmond, Rothamsted Experimental Station, for their criticism of the original manuscript.

MS. received 27 September 1965

\section{REFERENCES}

Ball, D. F. 1960. Relic-soil on limestone in South Wales. Nature, Vol. 187, No. 4736, p. 497-98.

Charlesworth, J. K. 1929. The South Wales end-moraine. Quarterly Journal of the Geological Society of London, Vol. 85 , Pt. 3, No. 339 , p. $335^{-58}$.

Crampton, C. B. 1960. Analysis of heavy minerals in the Carboniferous Limestone, Millstone Grit and soils derived from certain glacial gravels of Glamorgan and Monmouthshire. Transactions of the Cardiff Naturalists' Society, Vol. 87, p. $13^{-22}$.

Crampton, C. B. ig6r. An interpretation of the micro-mineralogy of certain Glamorgan soils; the influence of ice and wind. Journal of Soil Science, Vol. 12, No. 1, p. 158-71.

Crampton, C. B. 1964. Certain aspects of soils developed on calcareous parent materials in South Wales. Transactions of the Cardiff Naturalists' Society, Vol. 91, p. $4^{-1} 6$.

Griffiths, J. C. I939. The mineralogy of the glacial deposits of the region between the Rivers Neath and Towy, South Wales. Proceedings of the Geologists' Association, Vol. 5o, Pt. 4, p. 433-62.

Kubiena, W. L. 1953. Soils of Europe. London, Murby.

Pringle, T., and George, T. N. 1948. South Wales. Second edition. London, H.M.S.O. (British Regional Geology.)

Robertson, T. I932. The country around Merthyr Tydfil. Second edition. London, H.M.S.O. (Memoirs of the Geological Survey. England and Wales. The Geology of the South Wales Coalfield, Pt. V.)

Trueman, A. E. 1922. The Liassic rocks of Glamorgan. Proceedings of the Geologists' Association, Vol. 33, Pt. 4, p. $245-84$. 